\title{
INTRODUÇÃO AOS ESCRITOS SOBRE A PAZ DE NORBERTO BOBBIO
}

\section{INTRODUCTION TO WRITINGS ON THE PEACE OF NORBERTO BOBBIO}

Rafael Salatini'

RESUMO: O filósofo italiano Norberto Bobbio dedicou um número muito grande de escritos ao tema da paz e do pacifismo, que se distribuem em inúmeros textos dispersos que se iniciam nos anos 1940 e se encerraram apenas às vésperas de sua morte, em 2004, incluindo textos de diversas naturezas. Nesses textos, Bobbio analisou os seguintes problemas relacionados ao tema da paz: (a) o problema da definiçâo, (b) o problema da classificaçăo, (c) o problema da valoraçăo, (d) o problema do estado intermediário, (e) o problema do pacifismo, e (f) o problema do federalismo.

PALAVRAS-CHAVE: Bobbio, paz, pacifismo.

ABSTRACT: The Italian philosopher Norberto Bobbio devoted a very large number of writings to the theme of peace and pacifism, which are distributed in numerous scattered texts beginning in the 1940s and ending only on the eve of his death in 2004, including texts from various natures In these texts, Bobbio analyzed the following problems related to peace: (a) the problem of definition, (b) the problem of classification, (c) the problem of valuation, (d) the problem of pacifism, and (f) the problem of federalism.

KEYWORDS: Bobbio, peace, pacifism.

\section{OS TEXTOS SOBRE A PAZ E O PACIFISMO}

O filósofo italiano Norberto Bobbio dedicou um número muito grande de escritos ao tema da paz e do pacifismo, nos quais se encontram pelo menos três grandes influências: (a) o jusnaturalismo (de autores como Hobbes e especialmente Kant), (b) a teoria do federalismo (de autores como Kant, Kelsen, Cattaneo e Einaudi), (c) a teoria da năo-violência (de Gandhi) e a teoria da soluçăo pacífica de conflitos (de Galtung), entre outras influências mais pontuais. Tais influências se encontram ora mais ora menos expressas em inúmeros textos dispersos (que mereciam uma compilaçăo unitária) que se iniciam nos anos 1940 e se encerraram apenas às vésperas de sua morte,

Doutoranda em Direito Público e Mestre em Direito Laboral pela Faculdade de Direito da Universidade de Coimbra (FDUC). Pós-Graduada em Direito do Trabalho e Processo do Trabalho pela Escola da Magistratura Trabalhista da Paraíba (ESMAT 13) e em Processo Civil pelo Centro Universitário de Joáo Pessoa (UNIPÊ). Advogada. E-mail: «advcamilarodrigues@hotmail.com». 
em 2004, incluindo textos de diversas naturezas, entre os quais ensaios2, artigos3, atas de congressos, ${ }^{4}$ verbetes, ${ }^{5}$ introduçōes, ${ }^{6}$ entrevistas ${ }^{7}$ e cartas. ${ }^{8}$

Claramente, năo seria possível para mim analisar aqui todos os textos bobbianos dedicados a esse tema, que se encontram, a imensa maioria, ainda inéditos entre nós e dispersos em diversos livros, periódicos e publicaçōes avulsas. Todavia, muitos textos bobbianos sobre a paz e o pacifismo foram recentemente publicados no Brasil, ainda que de maneira igualmente dispersa, permitindo uma análise introdutória do pensamento bobbiano sobre o assunto, o que se pretende apresentar neste texto de maneira meramente introdutória.

2 Como "Federalismo e pacifismo" [Federalismo e pacifismo] (1947), "Pace e propaganda di pace" [Paz e propaganda de paz] (1952), "Teorie e dottrine sulla condizione della pace" [Teorias e doutrinas sobre a condiçâo da paz] (1975), "L'idea della pace e il pacifismo" [A ideia da paz e o pacifismo] (1975), "I concetti di pace e pacifismo nella filosofia politica" [Os conceitos de paz e pacifismo na filosofia política] (1979), "Alla marcia della pace" [Ä marcha da paz] (1981), "I diritti dell'uomo e la pace: Due problemi strettamente connessi" [Os direitos do homem e a paz: Dois problemas estreitamente conexos] (1982), "La pace attraverso il diritto" [A paz através do direito] (1983), "Il dialogo per la pace" [O diálogo pela paz] (1985), "La pace ha un futuro?" [A paz possui um futuro?] (1985), "Il dialogo per la pace" [O diálogo pela paz] (1989), "Erasmo, l'Europa della pace" [Erasmo, a Europa da paz] (1996), "Guerra e pace: Le strettoie del duemila" [Guerra e paz: O estrangulamento de dois milhôes] (1997), "L'idea della pace e il pacifismo" [A ideia de paz e o pacifismo] (1998), "I diritti, la pace e la giustizia sociale" [Os direitos, a paz e o pacifismo] (1999), "La guerra, la pace e il diritto" [A guerra, a paz e o direito] (1999), "Perché credo al pacifismo istituzionale" [Porque creio no pacifismo institucional] (2004).

3 Como "Riunire tutte le forze per la democrazia e la pace" [Reunir todas as forças para a democracia e a paz] (1956), "La marcia della pace" [A marcha da paz] (1961), "La federazione o della pace" [A federaçâo ou da paz] (1973), "Le varie forme di pacifismo" [As várias formas de pacifismo] (1976), "Discorso alla marcia della pace: Il discorso di Bobbio" [Discurso para a marcha da paz: O discurso de Bobbio] (1981), "Dove vola la colomba della pace?" [Onde voa a pomba da paz?] (1981), "La via della pace passa attraverso l'etica della tolleranza" [O caminho para a paz passa através da ética da tolerância] (1986), "Hobbes della pace" [Hobbes sobre a paz] (1988), "Hobbes, un modello per la pace perpetua" [Hobbes, um modelo para a paz perpétua] (1989), "Frontiere della pace" [Fronteiras da paz] (1998), "Guerra nei Balcani e pace ideale" [Guerra nos Balcás e paz ideal] (1999), "Il sogno di un uomo non violento: La marcia della pace" [O sonho de um homem náo-violenta: A marcha pela paz] (2001).

4 Como "Democrazia, pace e diritti dell'uomo" [Democracia, paz e direitos do homem] (1986); "Il dialogo per la pace" [O diálogo para a paz] (1986); "La pace ha un futuro?" [A paz possui um futuro?] (1987).

5 Como“Pace”[Paz](1976), "Pacifismo"[Pacifismo](1976), "Pace: Concetti, problemi eideali”[Paz: Conceitos, problemas e ideais] (1989).

6 Como "Pace o libertà? Introduzione al pensiero di Günther Anders" [Paz ou liberdade? Introduçâo ao pensamento de Günther Anders] (1961), "Introduzione alla 'Immanuel Kant, Per la pace perpetua, un progetto filosofico e altri scritti', a cura di Nicolao Merker" [Introduçăo à "Immanuel Kant, Para a paz perpétua, um projeto filosófico e outros escritos", sob ediçăo de Nicolao Merker] (1985), "Gian Paolo Gaviani, Un contadino in pace e in guerra" [Gian Paolo Gaviani, um fazendeiro na paz e na guerra] (1998).

7 Como "Solo la pace della paura?" [Somente a paz do medo?] (1975), "Discutiamone con Norberto Bobbio della pace e della guerra" [Discutamos com Norberto Bobbio sobre a paz e sobre a guerra] (1980), "Tra guerra e pace, tra realismo dei blocchi e autodeterminazione dei popoli: Faccia a faccia tra Norberto Bobbio e Gian Giacomo Migone" [Entre guerra e paz, entre o realismo dos blocos e autodeterminaçăo dos povos: Face à face entre Norberto Bobbio e Gian Giacomo Migone] (1982), "La pace è impotente?" [A paz é impotente?] (1983), "Sì, la pace si può difendere, ma convincendo le potenze che la guerra non è mai 'economica'" [Sim, a paz se pode defender, mas convencendo as potências que a guerra náo é mais "econômico"] (1983), "Professore di pace" [Professor de paz] (1985), "Passa per l'Europa la pace in Afghanistan" [Passa pela Europa a paz em Afeganistăo] (1987), "Grande pace piccole guerre" [Grande paz, pequenas guerras] (1993), "La riforma delle Nazioni Unite e la pace difficile" [A reforma das Naçôes Unidas e a paz difícil] (1995), "Io e Giulio illusi dalla pace" [Eu e Giulio iludidos sobre a paz] (1999).

8 Como "Messaggio in occasione della marcia della pace" [Mensagem pela ocasiâo da marcha da paz] (2000), "Filosofia, pacifismo, nonviolenza: Dalle lettere inedite a Giuliano Pontara (1961-2001)" [Filosofia, pacifismo, a năo-violência: Das cartas inéditas para Giuliano Pontara (1961-2001)] (2014). 
Entre os primeiros textos bobbianos sobre a paz, foram traduzidos para o português recentemente "La comunita internazionale e il diritto" [A comunidade internacional e o direito] (1951) e "Pace e propaganda di pace" [Paz e propaganda de paz] (1952), publicados ambos na Brazilian Journal of International Relations (sendo o último também publicado na coletânea intitulada Politica e cultura [Política e cultura] (originalmente publicada em 1955)). Esses textos permitem uma análise introdutória da formaçăo inicial do pensamento pacifista bobbiano, que se projeta concomitantemente sobre duas problemáticas: a crítica ao direito internacional público tradicional (como se vê no texto de 1951) e a crítica às propostas práticas de paz na política internacional (como se vê no texto de 1952).

No texto de 1951, que consiste numa ampla resenha crítica escrita sobre o livro La comunità internazionale e il diritto [A comunidade internacional e o direito] (1950) de Mario Giuliano, sâo discutidas inúmeras questōes clássicas de direito público internacional, entre as quais os temas da paz e da guerra e o tema do pacifismo.

Sobre o primeiro, Bobbio se voltaria contra a ideia exposta por Giuliano (defendendo a velha teoria da relaçăo entre democracia interna e paz internacional) segundo a qual, "para salvaguardar a paz, ele escreve, năo existe nada a mudar no ordenamento jurídico internacional, porque a paz depende exclusivamente da vontade dos Estados e basta que o direito internacional, como tal, năo impeça a colaboraçăo entre os Estados", e, "portanto, o que importa náo é mudar o regime jurídico dentro do qual se desenvolveu, até agora, a colaboraçăo dos Estados, mas promover uma decisiva orientaçăo em direçăo à paz da política dos Estados", de modo que "a orientaçăo em direçăo à paz, explica Giuliano, năo é de fato impedido pelo atual ordenamento internacional enquanto tal, mas unicamente pela organizaçăo interna de muitos Estados", e, "assim, para progredir em direçăo ao alcance da paz, năo é necessário reformar a organizaçăo internacional", mas, antes, "basta transformar o regime interno dos Estados (ou, ao menos, de uma parte destes)" (BOBBIO, 2016, p. 257).

Contrariamente, Bobbio (defendendo uma tese, de matriz federalista, que desenvolverá posteriormente) pergunta "o que diria Giuliano se eu lhe dissesse que para alcançar a paz social dentro de um Estado năo é necessário transformar a estrutura social e jurídica do Estado, mas apenas renovar por dentro o homem, de modo que seja sempre mais dotado de espírito de colaboraçăo em relaçâo aos seus semelhantes?", concluindo, criticamente que "esperar a paz náo da limitação da soberania absoluta, mas da boa vontade dos Estados é como aguardar a resoluçâo dos conflitos econômicos nâo da reforma da propriedade 'absoluta', que é própria do regime capitalista, mas da boa vontade dos proprietários" (BOBBIO, 2016, p. 257).

Continuando a mesma crítica contra o pacifismo voluntarista giulianiano, Bobbio afirma que, "quanto ao raciocínio com o qual Giuliano considera poder demonstrar a incoerência dos adversários, lá onde sustenta que ou a aspiraçâa à paz é real e basta, portanto, a boa vontade dos Estados, ou tal aspiraçăo năo existe e entăo tanto menos será possível transformar a atual postura internacional, porque năo se vê qual força poderia promover as reformas necessárias", concluindo que "tenho a suspeita que se se aceitasse por bem, acabar-se-ia por justificar o mais insolente conservadorismo e por inclinar-se na mais resoluta apologia da absoluta imobilidade", ou, em outras palavras, "quero dizer que se, para mudar de postura se devesse aguardar a boa disposiçáo de todos, mesmo daqueles que, da nova postura deveriam sofrer as desvantagens, os homens seriam ainda as 'bestas' de que fala Vico” (BOBBIO, 2016, p. 257). 
O tema náo seria um tema menor, mas, observa Bobbio ao final de sua resenha, relaciona-se com a própria relaçấo mais ampla entre direito e o tema da paz e do pacifismo. Bobbio afirma, assim, que "que a funçăo do direito năo seja a de estabelecer a ordem, serve a Giuliano para validar a sua ideologia pacifista", pois "a paz, segundo Giuliano, depende náo da reforma do direito internacional, mas da política pacífica dos Estados", concluindo Bobbio que, "naturalmente, resta se perguntar o que os homens pediram ao direito, ao longo dos séculos da sua história, que năo seja o estabelecimento da paz e da ordem, e que coisa possam pedir-lhe, uma vez que seja vedado a eles pedir-lhe ordem e paz" (BOBBIO, 2016, p. 261).

Mais, afirma que "limitamo-nos a formular este dilema: ou consideramos verdadeiramente que os Estados possam, após sua transformaçăo interna, exprimir uma permanente e indefectível vontade pacífica, e entăo năo será mais necessário o direito; ou admitimos que exista um direito internacional, e entăo devemos atribuir-lhe uma funçâo qualquer". E, por fim, afirma que, "se nâo queremos atribuir-lhe aquela de estabelecer a ordem e a paz, devemos dizer claramente qual valor este tenha ainda para nós, caso contrário, nâo podemos nos abster de reprovar por continuar a falar de uma instituiçăo da qual năo sabemos justificar a existência" (BOBBIO, 2016, pp. 261-262).

No texto de 1952, por sua vez, Bobbio analisara a paz como um valor no discurso pacifista do bloco soviético, no âmbito da guerra fria entre EUA e URSS, analisado sob dois pontos de vista lógicos, a sua natureza e a sua eficácia. Sobre a natureza da paz, Bobbio afirma que, considerando que "a paz, portanto, almeja, geralmente, conservar um status quo particularmente satisfatório", entăo "a paz é, essencialmente, conservadora", argumentando que "existe um exemplo histórico ilustre e eficazmente paradigmático de construçáo política fundada sobre o pressuposto de que o instinto fundamental do homem seja o instinto vital e, portanto, que a lei suprema da sua conduta seja a conservaçăo da paz: é o estado hobbesiano", reconhecendo que "este estado, como se nota, é um estado contrarrevolucionário, idealizado justamente para demonstrar a legitimidade da restauraçáo contra as reivindicaçóes da revoluçăo" (BOBBIO, 2015, 138).

Dessa forma, Bobbio deduz, quanto aos movimentos revolucionários, que, "se a paz tem funçấo essencialmente conservadora, surge uma suspeita legítima de que năo pode ser sinceramente pacifista quem năo tem interesse em manter o status quo" (BOBBIO, 2015, 138), afirmando que "entâo é claro que também para este novo movimento da paz, por mais que seja constituído, em grande parte, por adeptos de teorias revolucionárias, a paz tem uma funçâo essencialmente conservadora", pois "onde aconteceu a revoluçăo, o revolucionário se torna, necessariamente, defensor da conservaçâo do status quo", e, "já que para garantir o status quo é necessário um período de paz, năo existe nenhuma contradiçăo no fato de o revolucionário aderir a um movimento pela paz", restando apenas que "falta[ria] ver, no mais, como se pode conciliar a propaganda de paz, que é inevitavelmente conservadora, com a continuidade vitoriosa de fins revolucionários nos países em que a revoluçâo nâo foi ainda completa", considerando-se que "aqui parece que a conciliaçâo é mais difícil" (BOBBIO, 2015, 139).

Sobre a eficácia da paz, Bobbio argumentaria que "poderia se dizer, do mesmo modo, que para a defesa da paz năo é tăo necessário demonstrar as próprias intençôes pacíficas execrando o recurso à violência, declarando preferir as soluçôes de 
compromisso etc., mas é necessário eliminar as causas da guerra e, para eliminá-las, é necessário, antes de tudo, estar de acordo sobre o fato que a guerra depende desta mais que daquela causa" (BOBBIO, 2015, 141). De modo que, da ceitaçăo dessa objeçâo, derivaria duas consequências sobre o discurso pacifista do bloco soviético, quais sejam: "(1) Se é verdade que o acordo que une os Partisans da Paz năo é apenas o acordo sobre a paz desejável, mas também aquele sobre a crença na responsabilidade da América em provocar a nova guerra, aqueles que náo pertencem ao movimento e rejeitam aderir a ele, quando săo convidados, năo podem ser considerados belicitas, do momento em que a discordância deles náo se refere à paz desejável, mas somente a certos julgamentos relativos, de fato, às causas da guerra" (BOBBIO, 2015, 141). E: "(2) Justamente porque o acordo dos Partisans da Paz se refere nâo apenas à paz desejável em geral, mas à convicçâo de que a causa das guerras é o imperialismo americano, este movimento é partisan [partidário], no sentido que, entre as várias partes em conflitos, ou melhor, entre as duas grandes partes em conflito, tomou partido decisivamente em favor de uma contra a outra" (BOBBIO, 2015, 142).

Expostas essas duas premissas, Bobbio conclui sobre a contradiçăo do discurso de paz apresentado pelo bloco soviético, afirmando que "eles se oferecem para restabelecer a paz entre os adversários", conquanto "declaram desde o início, sem nenhuma reticência, que, dos dois adversários, um tem razâo e o outro está errado, que só se pode salvar a paz colocando-se de um único lado", de modo que "eles se apresentam como partisans [partidários] da paz, mas se apresentam também, ao mesmo tempo, como parentes, amigos, tendo relaçóes de interesse com uma das partes", concluindo que "a norma sobre a recusa dos juízes suspeitos de parcialidade năo vale para eles", e, portanto, "justamente porque năo vale, eis que perde a eficácia do movimento como movimento de pacificaçăo" (BOBBIO, 2015, 142).

Em outras palavras, "o comportamento do movimento năo é de pacificador ou de árbitro, porque ele nâo é, na realidade, um movimento de pacificaçâo", decorrendo do que "a contradiçăo entre objetivo e meio năo existe, năo porque os Partisans da Paz estejam dispensados, por privilégio único, da norma que considera incompatível o estado de amigo e o de árbitro, mas mais simplesmente porque eles nâo săo, na realidade (mesmo que muitos deles acreditem de boa-fé que o săo), árbitros ou pacificadores" (BOBBIO, 2015, 142).

\section{A TEORIA GERAL DA PAZ}

Após a escrita de inúmeros textos dispersos sobre a paz, entre os anos 1940 e 1950, discutindo fragmentadamente diversos aspectos teóricos e práticos da problemática da paz e do pacifismo, Bobbio exporia sua teoria da paz de forma mais sistemática nas décadas seguintes, em mais de uma oportunidade: especialmente, nos ensaios "Il problema della guerra e le vie della pace" [O problema da guerra e as vias da paz] (1966) e "L'idea della pace e il pacifismo" [A ideia da paz e o pacifismo] (1975), que seriam reunidos no livro Il problema della guerra e le vie della pace [O problema da guerra e as vias da paz] (1979), ${ }^{9}$ e nos verbetes "Pace" [Paz], que escreveu para seu

Bobbio teve a oportunidade de apresentar essa obra no Brasil, em 1982, em palestras na Universidade de Săo Paulo e na Universidade de Brasília (cf. CARDIM, 2001). 
Dizionario di politica [Dicionário de política] (1976 [organizado com N. Matteucci]; 1983 [ $2^{a}$ ed. revista e ampliada, organizada com N. Matteucci e G. Pasquino]); e "Pace: Concetti, problemi e ideali" [Paz: Conceitos, problemas e ideais], que escreveu para a Enciclopedia del novecento [Enciclopédia do século XX] (1989).

Nesses textos, Bobbio analisou, concentrada e sistematicamente, os seguintes problemas relacionados ao tema da paz: (a) o problema da definiçăo, (b) o problema da classificaçăo, (c) o problema da valoraçăo, (d) o problema do estado intermediário, (e) o problema do pacifismo, e (f) o problema do federalismo. Pode-se mesmo dizer que, nesses textos, Bobbio tentou apresentar (embora năo expresse com esses termos) uma teoria geral da paz, enquanto, nos inúmeros outros textos dedicados ao tema, mais desordenados, abordou os mesmos problemas apenas casuisticamente (quer dizer, em funçăo de questôes casuais). (Analisaremos tais aspectos doravante, introdutoriamente, com interesses maiores de desenvolvimento e aprofundamento posteriores, apontando por ora citaçōes diretas que serăo melhor analisadas futuramente.)

(a) Com relaçáo ao problema da definiçâo, considerando que os termos guerra e paz conformam uma antítese, Bobbio explica que, descritivamente, ambos costumam ser definidos circularmente, um termo em funçăo do outro, o termo significantemente mais fraco (paz) em funçăo do termo significantemente mais forte (guerra). Dessa forma, no verbete de 1976, Bobbio havia escrito que, "na acepçâo mais geral, paz significa ausência (ou cessaçăo, soluçấo, etc.) de um conflito", considerando que "a paz de que aqui pretendemos falar [...] trata-se da paz que póe termo ao tipo de conflito particular que é a guerra em todas as suas acepçōes" (BOBBIO, 1992b, pp. 910-911); enquanto afirmaria no verbete de 1989 que "prova disso é que na milenar literatura sobre o tema da guerra e da paz podem ser encontradas infinitas definiçôes de guerra, enquanto se encontra com frequência uma única definiçấo de paz, como fim, ou cessaçăo, ou conclusâo, ou ausência, ou negaçáo da guerra, qualquer que seja a sua definiçăo" (BOBBIO, 2000a, p. 510).

(b) Com relaçăo ao problema da classificaçâo, considerando, portanto, que o termo paz só pode ser definido em funçăo do termo guerra, e definindo, entăo, a guerra como "quando dois ou mais grupos políticos encontram-se entre si em uma relaçâo de conflito cuja soluçâo é confiada ao uso da força" (BOBBIO, 2000a, p. 513), Bobbio divisa dois significados específicos do termo paz: (i) a paz negativa (significado mais abrangente), "que indica um estado nas relaçōes internacionais antitético ao estado de guerra", e (ii) a paz positiva (significado mais restrito), "quando é usado para indicar o fim ou a conclusâo de uma determinada guerra" (BOBBIO, 2000a, p. 516). No verbete de 1976, Bobbio havia escrito que, "definida assim a guerra, a paz, entendida como năo-guerra, pode ser definida como uma situaçăo em que năo existe entre os grupos políticos relaçâo de conflito caracterizado por uma violência durável e organizada", continuando a afirmar que "daí deriva que: (a) dois grupos políticos podem estar em conflito entre si sem estar em guerra, já que o estado de paz năo exclui todo o conflito, mas só o conflito que se traduz em violência durável e organizada; (b) dois grupos políticos nâo se hâo de considerar em estado de guerra, se nas suas relaçóes se verificam casos de violência esporádica, como săo, por exemplo, os incidentes de fronteira" (BOBBIO, 1992b, p. 912). 
(c) Com relaçăo ao problema da valoraçâo, Bobbio aponta duas concepçóes axiologicamente positivas e duas axiologicamente negativas de paz. A primeira concepçáo axiologicamente positiva da paz - a mais repetida ao longo de toda a sua obra política - é a teoria filosófico-política da ordem, que pode ser observada especialmente em sua influência hobbesiana (na qual Bobbio chegou a partir da obra de Carl Schmitt), percebida claramente na passagem do texto "La pace attraverso il diritto" [A paz através do direito] (1983) em que afirma que, "com base nesta antítese [guerra-paz] está construída a teoria hobbesiana do Estado", segundo a qual "o estado de natureza é um estado de guerra uma vez que é um estado sem direito, no qual as leis positivas náo existem ainda e as leis naturais existem, mas năo săo eficazes; o estado civil é o estado no qual os homens, através de um acordo de cada um com todos os outros, instituem um sistema de leis válidas e eficazes com o objetivo de fazer com que cesse a guerra de todos contra todos, instaurando a paz", concluindo que "trata-se, portanto, de um estado pacífico exatamente porque é um estado jurídico e a passagem de um estado ao outro ocorre através de um ato jurídico que é o contrato", e, "portanto, enquanto o estado de natureza é um estado de guerra causado pela ausência de direito, o estado civil é um estado de paz porque consequência de um ato jurídico" (BOBBIO, 2000d, p. 565).

A segunda concepçáo axiologicamente positiva da paz - citada especialmente em seus verbetes sobre a paz - é a teoria teológica da justiça, que pode ser observada na passagem do verbete de 1976 em que Bobbio afirma que "fique bem claro que este conceito positivo de paz, sendo um conceito técnico do direito internacional, năo tem nada a ver com o conceito positivo de paz que se insere às vezes no discurso teológico e filosófico, onde por paz, em sentido positivo, se entende a 'verdadeira' paz, nâo uma paz qualquer, năo a paz ditada pelo vencedor, mas a paz com justiça", de forma que "o conceito teológico-filosófico de paz é positivo no sentido de que, rejeitando a definiçăo negativa de paz como ausência de guerra, a caracteriza como um estado de coisas que é portador de um valor positivo como a justiça, capaz, por si só, de tornar tal estado desejável" (BOBBIO, 1992b, pp. 912-913).

A primeira concepçâo axiologicamente negativa da paz é a teoria da guerra justa, sobre a qual Bobbio falara inúmeras vezes e sobre a qual publicara, por ocasiăo da chamada Guerra do Golfo Pérsico, o livro Una guerra giusta? [Uma guerra justa?] (1991), e sobre a qual escrevera no verbete de 1976 que "do mesmo modo que a guerra pode ser justa e, como tal, năo ser mais um valor negativo, também a paz pode ser injusta e, como tal, năo ser mais um valor positivo", esclarecendo que "o princípio segundo o qual se pode distinguir uma paz justa de uma paz injusta, é o mesmo que serve para a legítima defesa, que se requer seja proporcionada à ofensa, isto é, o princípio da chamada justiça corretiva, segundo o qual deve existir proporçâo entre delito e castigo, entre transgressâo e reparaçăo do direito", sentido em que "será, portanto, injusta uma paz que imponha aos vencidos um castigo, uma reparaçăo de danos, uma perda de territórios, ditados pelo espírito de vingança e năo pelo propósito de restabelecer a ordem lesada" (BOBBIO, 1992b, p. 914).

Todavia, Bobbio năo deixa de reconhecer que "é difícil estabelecer quando é que uma guerra é justa e quando é que uma paz é injusta", considerando "isto por falta de um juiz imparcial superior às partes na ordem internacional e, segundo as teorias classistas do Estado, como as geralmente aceitas pelos partidos revolucionários, por 
falta de um juiz imparcial também nas relaçôes internas do Estado", uma vez que, por um lado, "qualquer grupo político tende a considerar justa a guerra que faz e injusta a paz que é obrigado a suportar", e, por outro, "quanto ao tribunal da história, seu critério de julgamento nâo é a justiça ou a injustiça, mas sucesso" (BOBBIO, 1992b, p. 914).

Por fim, a segunda concepçấo axiologicamente negativa da paz é a teoria instrumental da paz, sobre a qual escrevera igualmente no mesmo verbete que "a segunda tendência, que propende a dar à guerra e à paz um valor que se afasta do modelo hobbesiano, segundo o qual a guerra é um mal absoluto e a paz um bem absoluto, é a que considera a guerra e a paz como valores instrumentais; consequentemente, se o valor do meio depende do valor do fim, săo válidos os princípios de que 'um fim bom justifica um meio mau', 'um fim mau injustifica também um meio bom'”, exemplificando com duas teorias, em primeiro lugar a teoria da guerra como mal necessário, que "está estreitamente ligada às teorias do progresso, segundo as quais, em diversa medida e sob diversos aspectos, o progresso da humanidade vem ou sempre veio através da guerra", sob três formas principais: (1) "A guerra é necessária para o progresso moral da humanidade, porque desenvolve energias que em tempo de paz năo têm possibilidade de se manifestar, e incita os homens ao exercício de virtudes sublimes, como a coragem heróica, o sacrifício de si mesmo em prol de um ideal, o amor à pátria, sem as quais nenhum grupo social teria condiçôes de sobreviver"; (2) "A guerra é necessária para o progresso social da humanidade, pois torna possível a unificaçăo de povos diversos em comunidades cada vez mais vastas, contribuindo assim para o fim último da história que é a unificaçăo do gênero humano"; e (3) "A guerra é necessária para o progresso técnico, porquanto a inteligência criadora do homem responde com maior vigor e resultados mais surpreendentes aos desafios que o contraste com a natureza e com os demais homens lhe apresenta de quando em quando; a guerra é certamente um dos maiores desafios que um grupo social tem de enfrentar para sobreviver" (BOBBIO, 1992b, p. 914).

Em segundo lugar está a teoria da paz como bem insuficiente, segundo a qual "considerar a paz como bem insuficiente significa que a paz năo pode, por si só, garantir uma vida social perfeita, onde os homens vivam felizes e prósperos", ponderando que "a paz é considerada geralmente como condiçâo, apenas como uma das condiçôes para a realizaçăo de outros valores, habitualmente considerados superiores, como a justiça, a liberdade e o bem-estar" e que "todos aqueles que consideraram a guerra como causa do progresso, consideraram a paz como causa, se năo do retrocesso, ao menos do nâo-progresso; viram nela a chave explicativa daquelas civilizaçóes que no século passado foram chamadas, em contraposiçăo às da progressiva Europa, de "estacionárias'" (BOBBIO, 1992b, p. 915).

(d) Com relaçâo ao problema do estado intermediário entre a guerra e paz, considerando que esses termos sâo antitéticos, Bobbio afirma que essa relaçāo de antítese pode ser considerada como uma relaçăo de contrariedade (que permite um estado intermediário) ou de contraditoriedade (que năo permite um estado intermediário). Nesse sentido, embora a tradiçâo do pensamento político ocidental, segundo Bobbio, tenha priorizado a interpretaçăo contraditória da antítese entre guerra e paz, Bobbio escreverá inúmeros textos preferindo pregar uma interpretaçâo contrária da relaçâo entre guerra e paz, propondo a figura intermediária do tertium [terceiro] para analisar o sistema internacional, incluindo desde o tertium nom datur [terceiro ausente] 
até o tertium datur [terceiro presente], passando por posiçōes intermediárias. Sobre a importância da figura do tertium [terceiro] para o tema da paz, Bobbio escreve (utilizando os conceitos freundianos de "estado polêmico" e "estado agonístico"), no verbete de 1989, que "a importância do terceiro em uma estratégia de paz nunca será suficientemente enfatizada", pois, "quando [o terceiro] permanece neutro, encontra-se em uma situaçăo de estraneidade ao conflito", e, "com base na presença ou na ausência de um terceiro em um conflito, funda-se a distinçấo, já mencionada, entre estado polêmico, do qual o terceiro está excluído, e estado agonal, no qual existe o terceiro e que, portanto, pode ser chamado de terceiro incluso", sendo que "o primeiro, que é o estado de guerra por excelência, é diádico; o segundo, que é por excelência o estado de paz, vale dizer, aquele no qual os conflitos sâo solucionados pela presença de um terceiro sem que seja necessário recorrer ao uso da força recíproca, é triádico" (BOBBIO, 2000a, p. 540).

(Os estudos bobbianos sobre a figura do tertium [terceiro] săo baseados especialmente numa obra de P.P. Portinaro intitulada Il terzo [O terceiro] (1986), citada expressamente no artigo "Democrazia e sistema internazionale" [Democracia e sistema internacional] (1989), no qual Bobbio apresentaria, ainda que sucintamente, uma completa análise do sistema internacional em funçăo desse conceito. Sobre o problema do tertium [terceiro] na obra bobbiana, năo se pode esquecer, por fim, uma obra justamente intitulada Il terzo assente [O terceiro ausente] (1988), no qual săo compilados inúmeros textos do autor sobre este último tema ${ }^{10}$ ).

(e) Com relaçấo ao problema do problema do pacifismo, Bobbio apresenta a definiçāo, no verbete "Pacifismo" [Pacifismo] (1976), segundo a qual "por pacifismo se entende uma doutrina, ou até mesmo só um conjunto de idéias ou de atitudes, bem como o movimento correspondente, marcados por estas duas características: a) condenaçấo da guerra como meio apto para resolver as contendas internacionais; b) consideraçăo da paz permanente ou perpétua entre os Estados como um objetivo possível e desejável" (BOBBIO, 1992a, p. 876). A partir dessa definiçăo - e depois de distinguir outras formas mais genéricas de pacifismo, como o pacifismo ético-religioso (como o irenismo erasmiano, que Bobbio analisaria rapidamente no texto "Omaggio a Erasmo" [Homenagem a Erasmo] (1997)), o pacifismo econômico (tanto em seu formato liberal, apresentado nas teorias de Cobden e Comte, quanto em seu formato socialista, apresentado nas teorias de Lênin e Luxemburgo) e o pacifismo político (apresentado nas teorias de Voltaire e Kant) -, Bobbio divisa, inicialmente, duas formas de pacifismo, o pacifismo passivo, que considera a paz "como resultado de uma evoluçáo fatal da sociedade humana", e o pacifismo ativo, que considera a paz "como conseqüência do esforço inteligente e organizado do homem com vistas a um fim desejado" (BOBBIO, 1992a, p. 876).

No mesmo verbete, afirma que "o pacifismo passivo esgotara sua funçăo, quando conseguiu demonstrar que a guerra já nâo era necessária para o desenvolvimento

10 Especialmente os textos "Pace o libertà? Introduzione al pensiero di Günther Anders" [Paz ou liberdade? Introduçăo ao pensamento de Günther Anders] (1961), "Alla marcia della pace" [Ä marcha da paz] (1981), "I diritti dell'uomo e la pace: Due problemi strettamente connessi" [Os direitos do homem e a paz: Dois problemas estreitamente conexos] (1982), "La pace attraverso il diritto" [A paz através do direito] (1983), "Il dialogo per la pace" [O diálogo pela paz] (1985) e "La pace ha un futuro?" [A paz possui um futuro?] (1985). 
da humanidade", enquanto "o pacifismo ativo quis demonstrar, em vez disso, que a guerra é um acontecimento negativo e danoso que tem de ser impedido", concluindo que "a característica das correntes pacifistas de hoje, da era da guerra atômica, é a de se haverem transformado em pacifismo ativo: em face do perigo da destruiçấo de todo o vestígio humano sobre a terra, a paz é um bem sumamente importante, ao qual é preciso tender com esforço tenaz e unânime" (BOBBIO, 1992a, p. 877).

Dividido o pacifismo em pacifismo passivo e ativo, Bobbio privilegiará em seus textos o tema do pacifismo ativo, dividindo especialmente este último em três subformas de pacifismo (que analisará em diversos textos posteriores): (i) o pacifismo instrumental, voltado para os meios que se usam para fazer a guerra, (ii) o pacifismo institucional, voltado para as instituiçōes que a tornam possível, e (iii) o pacifismo finalístico, voltado para o próprio homem, cada um dos quais, por sua vez, subdividido em duas formas. Sobre o primeiro, escreve (sempre no mesmo verbete) que "no pacifismo instrumental convém distinguir a açâo orientada à destruiçăo ou à drástica limitaçâo dos instrumentos bélicos (doutrina e política do desarmamento), da açăo tendente a substituir os meios violentos pelos nâo violentos e, conseqüentemente, a obter, por outros meios, o mesmo resultado (teoria e prática da nâo-violência, em particular a doutrina do Satyagraha de Ghandi)"; enquanto sobre o segundo, escreve que "ao pacifismo institucional estăo ligadas tanto as teorias que visam à constituiçấo do Estado universal, como as que visam à aboliçâo do Estado, isto é, tanto o pacifismo que dissemos jurídico, como, em última análise, a doutrina comunista e anárquica"; e, por fim, sobre o terceiro, escreve que "no pacifismo finalístico juntam-se, enfim, quer o pacifismo ético-religioso que tem em vista a conversâo e transformaçăo moral do homem, o homem novo, quer o pacifismo científico, que tem em vista neutralizar ou canalizar em outras direçôes o instinto de agressăo; junta-se aí tanto o pacifismo dos sacerdotes e dos moralistas, quanto o dos homens da ciência" (BOBBIO, 1992a, p. 877).

Comparando as três formas de pacifismo ativo, Bobbio, por fim, conclui que "as três formas de pacifismo dispôem-se numa ordem progressiva de maior complexidade e profundidade: a primeira finca-se no plano das técnicas específicas; a segunda estende-se ao plano da organizaçấo social global; a terceira vai mais além, até o homem, isto é, até o autor e usuário das técnicas e das várias formas de organizaçâo social", de modo que "uma vez que a viabilidade está em relação inversa com a complexidade e a eficácia em relaçăo direta com a profundidade, poder-se-á também dizer que qualquer destes três caminhos para a paz será tanto mais viável quanto menos eficaz, e vice-versa", ultimando que "isto permite colocá-los numa ordem decrescente de viabilidade e numa ordem crescente de eficácia, partindo do desarmamento, que é o caminho mais viável, mas também o menos eficaz, até à reforma moral do homem, que é certamente o caminho mais eficaz, se bem que, no plano real, o menos viável" (BOBBIO, 1992a, p. 877).

A mesma teoria do pacifismo, todavia, já estava presente, alguns anos antes, no texto "Il problema della guerra e le vie della pace" [O problema da guerra e as vias da paz] (1966), no qual analisara introdutoriamente a teoria da guerra, da velha teoria da guerra justa até a contemporânea teoria da guerra atômica, concluindo que esta contribuiu decisivamente para a superaçâo dos argumentos de todas as velhas teorias de justificaçăo da guerra, tornando possível o desenvolvimento de uma consciência 
atômica que desemboca, por fim, no pacifismo ativo, apresentando exatamente as mesmas três subdivisōes que seriam adjudicadas no verbete de 1976. Escrevia entăo que "o pacifismo ativo se move em três direçóes conforme procure a soluçăo do seu próprio problema - eliminaçăo da guerra e instauraçăo de uma paz perpétua -, agindo ou sobre os meios ou sobre as instituiçôes ou sobre os homens", podendo-se "falar de um pacifismo instrumental no primeiro caso, institucional no segundo, finalista no terceiro" (BOBBIO, 2003, p. 97).

Depois de explicar igualmente uma a uma as formas de pacifismo positivo, considerando (tomando como critérios de julgamento a exequibilidade e a eficácia) novamente o pacifismo instrumental o mais exequível, mas o menos eficaz, e o pacifismo finalista o mais eficaz, mas o menos exequível, Bobbio já defendia o pacifismo institucional, e, dentre os dois subtipos, especialmente o pacifismo jurídico, que fornece uma "posiçāo intermediária", sendo "mais exequível mas menos eficaz que o pacifismo finalista" e "mais eficaz mas menos exequível que o instrumental" (BOBBIO, 2003, p. 110). (Dez anos depois, a mesma tipologia (que estava ausente no verbete sobre a paz de 1976, justamente porque estava presente no verbete sobre o pacifismo no mesmo dicionário), reapareceria no verbete sobre a paz de 1989.)

Restaria apenas a afirmar que o pacifismo jurídico, reiteradamente defendido por Bobbio, năo é senáo aquela forma de paz que fora defendida numa pequena obra kelseniana de 1944, lembrada expressamente por Bobbio, entre outras, na pequena passagem do citado texto "La pace attraverso il diritto" [A paz através do direito] (1983) em que afirma que "somente levando em consideraçâo esses dois níveis [preventivo e repressivo] sobre os quais se estabelece uma ordem jurídica consegue-se dar um sentido preciso à expressăo, tâo frequentemente usada, em especial nas relaçôes internacionais, 'paz através do direito"', precisando que "Peace through law [Paz pelo direito] é o título de uma conhecida obra de Kelsen sobre o direito internacional" (BOBBIO, 2000d, p. 566).

Por fim, uma terceira classificaçăo de pacifismo, distinta das demais, com base nas diversas filosofias da história modernas, é apresentada no texto "L'idea della pace e il pacifismo" [A ideia da paz e o pacifismo], distinguindo o pacifismo iluminista, segundo o qual "nâo haverá verdadeira paz senâo quando os povos tiverem tomado posse do poder estatal", o pacifismo positivista, segundo o qual "năo haverá verdadeira paz senăo quando a organizaçấo militar da sociedade no seu conjunto năo tiver desaparecido diante do avanço do industrialismo", e o pacifismo socialista, segundo o qual "năo haverá verdadeira paz senăo quando a sociedade dominada por grupos minoritários, que só podem conservar o poder exercendo a violência fora e dentro dos limites do Estado, por uma nova forma de sociedade", afirmando que "esses três tipos de pacifismo se dispóem em três diferentes níveis de profundidade: no nível da organizaçáo política, o primeiro; da sociedade civil, o segundo; do modo de produçăo, o terceiro"; e que "o que eles têm em comum é considerar a paz o resultado inevitável do processo histórico, e considerar esse processo uma forma de progresso porque nele está inscrita como resultado necessário a transiçâo para uma sociedade na qual reinará, embora por razóes diversas, a paz perpétua, ou na qual, mais precisamente, ir-se-á desenvolvendo uma forma de convivência tăo diferente daquela que caracterizou a história humana até hoje a ponto de tornar cada vez mais improvável a guerra como meio de resolver os conflitos (concepçăo humanista), ou cada vez mais 
disseminados os conflitos que náo têm necessidade da guerra para serem resolvidos (concepçăo positivista), ou ainda cada vez mais raros os próprios conflitos que opóem entre si os indivíduos e os grupos nas sociedades divididas em classes antagônicas (concepçăo do marxismo evolucionista)" (BOBBIO, 2003, pp. 162-163).

(f) Por fim, com relaçâo ao problema do federalismo, pode-se dizer que o corolário lógico e político da teoria da paz e do pacifismo bobbianos seria a teoria do federalismo, sobre o qual Bobbio escrevera igualmente inúmeros textos ${ }^{11}$. Em inúmeras ocasióes, Bobbio referir-se-á ao projeto federalista como o maior objetivo internacional relacionado aos temas da paz e do pacifismo, apontando as inúmeras propostas históricas, em nível filosófico e em nível prático, de federalismo conhecidas desde o século XVIII. No citado texto "L'idea della pace e il pacifismo" [A ideia da paz e o pacifismo] (1975), Bobbio escreveria, sob o ponto de vista filosófico, que, "como se sabe, a história do pacifismo tem início com alguns projetos, cogitados e construídos em gabinetes por pensadores ou diplomatas isolados, os quais, embora interpretando uma certa linha de tendência, năo representam uma forma histórica capaz de colocá-la em açăo", sendo que "os três principais săo os do abade de Saint-Pierre Projet pour rendre la paix perpetuélle en Europe [Projeto para tornar a paz perpétua na Europa] (1713), o de Kant, Pela paz perpétua (1795), o de Saint-Simon e Thierry, De la réorganisation de la sociétè européenne [Da reorganizaçăo da sociedade europeia] (1814)", concluindo que "os três săo representativos daquela forma mais elementar de pacifismo que em outra passagem chamei 'pacifismo jurídico' ou da 'paz através do direito'" (BOBBIO, 2003, p. 159).

Percebe-se, todavia, que a maior influência federalista no pensamento político bobbiano - certamente a mais mencionada em seus escritos - será aquela encontrada na clássica teoria da paz perpétua, que Bobbio aprecia especialmente na formulaçấo kantiana, que desenvolveu, entre inúmeros outros textos, na parte final de seu livro Diritto e Stato nel pensiero di Emmanuel Kant [Direito e Estado no pensamento de Immanuel Kant] (1969), no qual escreve (resumindo o projeto kantiano) que "a teoria da paz perpétua no pensamento de Kant está fundamentada em quatro pontos principais", quais sejam: em primeiro lugar, "os Estados nas suas relaçōes externas vivem ainda num estado nâo-jurídico (seria melhor dizer num estado jurídico provisório"; em segundo lugar, "o estado de natureza é um estado de guerra e portanto um estado injusto (da mesma maneira como é injusto o estado de natureza entre os indivíduos)"; em terceiro lugar, "sendo esse estado injusto, os Estados têm o dever de

11 Esses textos incluem: (1) ensaios, como "Il federalismo e l'Europa" [O federalismo e a Europa] (1946), "Federalismo e socialismo" [Federalismo e socialismo] (1946), "Federalismo e pacifismo" [Federalismo e pacifismo] (1947), "Federalismo o funzionalismo?" [Federalismo ou funcionalismo?] (1947), "Il federalismo nel dibattito politico e culturale della Resistenza" [0 federalismo no debate político e cultural da Resistência] (1982), "Le due facce del federalismo" [As duas faces do federalismo] (1996), "Federalismo vecchio e nuovo" [Federalismo velho e novo] (1996), "Il mio federalismo attraverso Cattaneo" [Meu federalismo através de Cattaneo] (1998); "Einaudi: L'utopia dell'Europa" ["Einaudi: A utopia da Europa] (1998); (2) artigos, como "Il federalismo" [O federalismo] (1969), "Il federalismo di Carlo Cattaneo" [O federalismo de Carlo Cattaneo] (1969), "Luigi Einaudi, federalista" [Luigi Einaudi, federalista] (conferência apresentada em 1991 e publicada em 1993), "Devolution e federalismo" [Descentralizaçâo e federalismo] (2006); (3) prefácios, como "Silvio Trentin, federalismo e libertà, scritti teorici (1935-1943)" [Silvio Trentin, federalismo e liberdade, escritos teóricos (1935-1943)] (1987); etc. 
sair do mesmo e fundar uma federaçâo de Estados, segundo a ideia de um contrato social originário, ou seja, 'uma uniâo dos povos por meio da qual eles sejam obrigados a náo se intrometer nos problemas internos uns dos outros, mas a proteger-se contra os assaltos de um inimigo externo'"; e, em quarto lugar, "essa federaçăo năo institui um poder soberano, ou seja, năo dá origem a um Estado acima dos outros Estados, ou superestado, mas assume a figura de uma associaçăo, na qual os componentes permanecem num nível de colaboraçâo entre iguais (societas aequalium), como se dos dois contratos que, segundo a doutrina tradicional do jusnaturalismo, eram necessários para a formaçăo do Estado, o pactum societas e o pactum subiectionis, tivesse que ser efetivado, para resolver os conflitos entre os Estados, somente o primeiro e de forma alguma o segundo" (BOBBIO, 1997, pp. 159-160).

À frente, continua, afirmando que "de como seria possível chegar-se a esta federaçăo de Estados, que deveria limitar-se a ser uma confederaçăo e năo chegaria a ser um verdadeiro estado federal, Kant se fixa em alguns pontos aos quais dá a forma de artigos de um tratado imaginário", pelo que "distingue seis artigos preliminares, que estabelecem as condiçôes necessárias para que sejam eliminadas as principais razôes de guerra entre os Estados, e três artigos definitivos, nos quais săo estabelecidas as condiçóes necessárias para o estabelecimento de uma paz duradoura" (BOBBIO, 1997, p. 160).

Sobre o tema da paz perpétua no pensamento kantiano, náo se pode deixar de mencionar que Bobbio estender-se-ia, futuramente, mais extensamente, na introduçáo que escreveu para o texto kantiano que se intitulou "Introduzione alla 'Immanuel Kant, Per la pace perpetua, un progetto filosofico e altri scritti', a cura di Nicolao Merker" [Introduçâo à "Immanuel Kant, Para a paz perpétua, um projeto filosófico e outros escritos", sob ediçăo de Nicolao Merker] (1985).

Entre os pensadores federalistas contemporâneos, Bobbio recorrerá inúmeras vezes a dois grandes representantes italianos: em primeiro lugar, Carlo Cattaneo, sobre o qual publicou uma obra integral intitulada Una filosofia militante: Studi su Cattaneo [Uma filosofia militante: Estudos sobre Cattaneo] (1971) -, sobre o qual escreveu, no texto "Carlo Cattaneo e le riforme" [Carlo Cattaneo e as reformas] (1974), que "certamente um dos momentos mais interessantes do reformismo cattaniano é o momento dos escritos sobre a organizaçáo do Estado administrativo, militar e escolástico depois de realizada a unificaçáo, quando, de abstrato derrotado federalista, torna-se regionalista que reflete sobre os fatos concretos da história e da geografia italiana, desaconselhando uma unificaçăo apressada, uniforme e indiferenciada da legislaçăo para todo o reino" (BOBBIO, 2000b, p. 635).

E, em segundo lugar, Luigi Einaudi, sobre o qual escreveu, no texto "Luigi Einaudi, federalista" [Luigi Einaudi, federalista] (1993), que "năo existe história do federalismo europeu que nâo reconheça Einaudi como uma autoridade, como um dos mais iluminados e férreos combatentes doutrinais, defensor da ideia federalista aplicada à Europa e, portanto, um dos pais do movimento federalista europeu" (BOBBIO, 2014, p. 550).

Sob o ponto de vista prático, Bobbio avaliaria, para citar apenas uma rápida passagem (entre inúmeras outras), no livro Stato, governo e società [Estado, governo e sociedade] (1985) - que compila os textos bobbianos escritos para a Enciclopédia 
Einaudi -, que "a república universal dos Estados confederados, proposta por Kant na sua Paz perpétua, representa uma verdadeira e própria alternativa, que se pode dizer democrática pela sua inspiraçăo e por seus possíveis desenvolvimentos, à idéia medieval do império universal", e que "desenvolvimentos parciais desta república universal contraposta ao império universal foram a Sociedade das Naçóes após a primeira guerra mundial e a Organizaçăo das Naçôes Unidas após a segunda: mesmo na fórmula preferida 'naçōes unidas', os Estados que concorreram para a formaçâo da nova confederaçâo universal revelaram em quais precedentes se tinham inspirado (as Províncias unidas [Países Baixos], os Estados unidos [EUA])" (BOBBIO, 2000e, p. 103).

Por fim, seria preciso mencionar que Bobbio escreveria inúmeros textos sobre a ONU, dentre os quais se deve destacar "Le Nazioni Unite dopo quarant'anni" [As Naçōes Unidas quarenta anos depois] (1985) e "In lode dell'ONU" [Em louvor da ONU] (1987), ambos textos que foram compilados em na citada obra Il terzo assente [O terceiro ausente], e principalmente o importantíssimo ensaio “Democrazia e sistema internazionale" [Democracia e sistema internacional] (1989), que seria compilado na ediçấo de 1991 de Il futuro della democrazia [O futuro da democracia] (1984; acrescido em 1991), e no qual afirmaria que "apenas com a constituiçấo da Sociedade das Naçôes em primeiro lugar e depois com a Organizaçăo das Naçôes Unidas é que se experimentou uma terceira via, a da superaçăo da anarquia sem cair na autocracia ou, para usar conceitos acima aclarados, da anomia sem cair na heteronomia" (BOBBIO, 2011, p. 198).

Como dito inicialmente, Bobbio possui uma imensa produçâo intelectual dedicada aos temas da paz e do pacifismo (e, correlatamente, ao tema do federalismo), cuja análise possui grande importância, năo apenas especialmente para a compreensâo desses temas, mas igualmente para o estudo das relaçóes internacionais no mundo contemporâneo, em que os valores pacifistas têm crescido na proporçâo direta em que crescem os temores de novas guerras de natureza mundial. Um estudo maior dessa temática deverá ser realizado posteriormente, sendo por ora essas as primeiras incursōes no tema que estou em condiçōes de apresentar neste texto. 


\section{REFERÊNCIAS BIBLIOGRÁFICAS}

BOBBIO, Norberto. A comunidade internacional e o direito. Trad. Erica Salatini. Rev. Rafael Salatini. BJIR - Brazilian Journal of International Relations, v. 05, n. 01, jan/ abr, 2016, pp. 246-262.

. A paz: O conceito, o problema, o ideal. In: BOBBIO, Norberto. Teoria geral da política: A filosofia política e as liçôes dos clássicos. Org. Michelangelo Bovero. Trad. Daniela Beccaccia Versiani. Rio de Janeiro: Campus, 2000a, pp. 509-543. [Também como: BOBBIO, Norberto. Paz. In: BOBBIO, Norberto. 0 filósofo e a política: Antologia. Sel. e org. José F. Fernández Santillan. Trad. César Benjamin/Vera Ribeiro. Rio de Janeiro: Contraponto, 2003, pp. 317-349.]

. Carlo Cattaneo e as reformas. In: BOBBIO, Norberto. Teoria geral da política: A filosofia política e as liçōes dos clássicos. Org. Michelangelo Bovero. Trad. Daniela Beccaccia Versiani. Rio de Janeiro: Campus, 2000, pp. 618-637.

. Democracia e sistema internacional. In: BOBBIO, Norberto. 0 futuro da democracia: Uma defesa das regras do jogo. Trad. Marco Aurélio Nogueira. Rev. Marco Antônio Corrêa/Denise Scofano. Rio de Janeiro: Paz e Terra, 2000. (171 p.), pp. 187-207. [Também como: BOBBIO, Norberto. Democracia e sistema internacional. In: BOBBIO, Norberto. Três ensaios sobre a democracia. Trad. Sérgio Bath. Rev. Leila Gebrim. Sáo Paulo: Cardim \& Alario, 1991, pp. 59-78; e como: BOBBIO, Norberto. Democracia e sistema internacional. In: BOBBIO, Norberto. 0 filósofo e a política: Antologia. Sel./org. José F. Fernández Santillan. Trad. César Benjamin/Vera Ribeiro. Rio de Janeiro: Contraponto, 2003, pp. 350-367.]

Homenagem a Erasmo. Trad. Erica Salatini. Rev. Rafael Salatini. BJIR - Brazilian Journal of International Relations, v. 05, n. 03, set/dez 2016, pp. 690-695.

BOBBIO, Norberto. Introduçâo a Para a paz perpétua de Immanuel Kant. Trad. Erica Salatini. Rev. Rafael Salatini. BJIR - Brazilian Journal of International Relations, v. 06, n. 01, 2017, pp. 223-237.

. Luigi Einaudi, federalista. Trad. Erica Salatini/Gesualdo Maffia. Rev. Rafael Salatini.

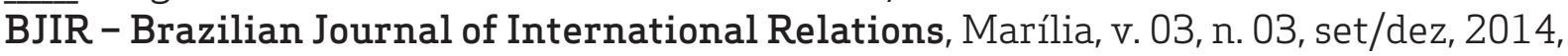
pp. 548-565.

. Os direitos do homem e a paz. In: BOBBIO, Norberto. Teoria geral da política: A filosofia política e as liçôes dos clássicos. Org. Michelangelo Bovero. Trad. Daniela Beccaccia Versiani. Rio de Janeiro: Campus, 2000, pp. 497-501. [Também como: BOBBIO, Norberto. Os direitos do homem e a paz. In: BOBBIO, Norberto. 0 terceiro ausente: Ensaios e discursos sobre a paz e a guerra. Org. Pietro Polito. Trad. Daniela Beccaccia Versiani. Rev. Frederico Diehl/Valdemar Bragheto Junqueira. Barueri, SP: Manole, 2009, pp. 111-117.]

Pacifismo. In: BOBBIO, Norberto; MATTEUCCI, Niccola \& PASQUINO, Gianfranco (orgs.). Dicionário de política. Trad. Carmen C. Varrialle et al. Brasília: UnB, 1992a, v. 2, pp. 875-877. 
. Paz e direito. In: BOBBIO, Norberto. Teoria geral da política: A filosofia política e as liçóes dos clássicos. Org. Michelangelo Bovero. Trad. Daniela Beccaccia Versiani. Rio de Janeiro: Campus, 2000d, pp. 564-573.

BOBBIO, Norberto. Paz e propaganda de paz. Trad. Erica Salatini. Rev. Rafael Salatini. BJIR - Brazilian Journal of International Relations, v. 04, n. 01, jan/abr, 2015, pp. 135145. [Também como: BOBBIO, Norberto. Paz e propaganda de paz. In: BOBBIO, Norberto. Política e cultura. Org. Franco Sbarberi. Trad. Jaime A. Clasen. Sáo Paulo: Unesp, 2015, pp. 131-143.]

Paz. In: BOBBIO, Norberto; MATTEUCCI, Niccola \& PASQUINO, Gianfranco (orgs.). Dicionário de política. Trad. Carmen C. Varrialle et al. Brasília: UnB, 1992, v. 2, pp. 910-916.

Direito e Estado no pensamento de Emanuel Kant. Trad. Alfredo Fait. Rev. Esteváo Rezende Martins. Brasília: UnB, 1997. (168 p.) [Também publicado como: BOBBIO, Norberto. Direito e Estado no pensamento de Emanuel Kant. Trad. Alfredo Fait. Sáo Paulo: Mandarim, 2000. (266 p.)]

Estado, governo, sociedade: Para uma teoria geral da política. Trad. Marco Aurélio Nogueira. Rio de Janeiro: Paz e Terra, 2000f. (178 p.)

O problema da guerra e as vias da paz. Trad. Álvaro Lorencini. Săo Paulo: Unesp, 2003. (181 p.)

. 0 terceiro ausente: Ensaios e discursos sobre a paz e a guerra. Org. Pietro Polito. Trad. Daniela Beccaccia Versiani. Rev. Frederico Diehl/Valdemar Bragheto Junqueira. Barueri, SP: Manole, 2009. (309 p.)

. Una guerra giusta? Sul conflitto del Golfo. Venezia: Marsílio, 1991. (96 p.)

BONANATE, Luigi. El pensamiento internacionalista de Norberto Bobbio. Trad. José F. Fernández Santillan. México: Fontamara, 2009. (140 p.)

CARDIM, Carlos Henrique (org.). Bobbio no Brasil: Um retrato intelectual. Brasília: UnB; SP: Imprensa Oficial, 2001. (159 p.)

ZOLO, Danilo. Luzes e sombras do "pacifismo jurídico" de Norberto Bobbio. Trad. Carlo Alberto Dastoli. In: TOSI, Giuseppe (org.). Norberto Bobbio: Democracia, direitos humanos, guerra e paz, vol. 2. Joăo Pessoa: UFPB, 2013, pp. 321-333.

. Los seńores de la paz: Una crítica del globalismo jurídico. Trad. Roger Campione. Madrid: Dykinson, 2005. (142 p.) 